\title{
Democratic Education in the Mode of Populism
}

\author{
Andreas Mårdh ${ }^{1}$ (D) Ásgeir Tryggvason ${ }^{1}$
}

Published online: 19 January 2017

(C) The Author(s) 2017. This article is published with open access at Springerlink.com

\begin{abstract}
This paper seeks to bring John Dewey's pragmatist philosophy of democratic education and the public into dialogue with Ernesto Laclau's theory of populism. Recognizing populism as an integral aspect of democracy, rather than as its antithesis, the purpose of this paper is to provide a theoretical account of populism as being of educational relevance in two respects. First, it argues that the populist logic specifies a set of formal elements by which democratic education could operate as a collective enterprise. Second, it asserts that the notion of populism supplements any congenial understanding of democratic education by bringing political demands, conflicts and affects to the fore. Finally, the paper discusses the risks and possibilities inherent in visualizing populism as an educational modus.
\end{abstract}

Keywords Populism - Democratic education - The public $\cdot$ Demands · Affect · Antagonism

\section{Introduction}

Stating that the amount of scholarly work on the topic of democratic education is too vast to fathom in its entirety is no exaggeration, particularly when considering that recurring themes range from students' political subjectivity (e.g. Biesta 2011; Straume 2016) to educational thought on cosmopolitanism (e.g. Merryfield and Duty 2008; Spector 2015). However, despite the significant body of literature, populism as an issue of contemporary relevance for democratic education lacks a comprehensive theoretical account. The somewhat tarnished reputation of the concept could account for its obscurity in educational

Andreas Mårdh

andreas.mardh@oru.se

1 School of Humanities, Education and Social Sciences, Örebro University, Fakultetsgatan 1, 70182 Örebro, Sweden 
thought, but considering the recent political developments in Europe, America and Asia, ${ }^{1}$ scholars can no longer afford to ignore the implications of populism in the context of education.

In an attempt to amend this shortcoming, it is the purpose of the following paper to argue that the notion of populism, as a form of political articulation, has something substantial to offer a democratic conception of education. Subsequently, the paper aims to provide the reader with a particular theoretical account which suggests that populism is of relevance in two respects: first, that it specifies a set of logical elements by which democratic education could operate if regarded as a joint or collective enterprise and second, that it could supplement any congenial understanding of democratic education by bringing political demands, conflicts and affects to the fore.

Although populism is not entirely new to educational research, previous studies have mostly regarded the phenomenon as an object of historical inquiry (Lauglo 1995; Tjeldvoll 2002), an element of educational policy (Conroy 2010), or as a variable in young people's political engagement (Pollock et al. 2015; Spruyt 2014). In contrast to these empirical accounts, this study offers a theoretical equivalent that seeks to recognize populism as an integral aspect of democracy, rather than its antithesis.

A guiding principle for this theoretical exposition is the wittgensteinian notion of aspect dawning as defined by Norval (2007). In her account, Norval contrasts aspect dawning with the otherwise naturalized and sedimented ways in which humans take their perceptions for granted. As such, the dawning of an aspect indicates an emergence and a re-articulation of meaning about a particular object. However, this does not mean that humans, while in the midst of dawning a new aspect, simply substitute an already existing perspective for a novel one. On the contrary, aspect dawning brings an awareness of the possibility of recalling and switching between different ways of perceiving. Continuity and change in the establishment and maintenance of meaning are thus (to a certain extent) simultaneous: "If aspect dawning connotes the new, that element of initial surprise, when a novel set of connections or articulations offer us a picture that allows us to make some sense of a disruptive experience, aspect change may be utilized to capture the sense in which the initial moment of dawning could be reactivated at a later stage" (Norval 2007, p. 134). In short, aspect dawning is the manner in which our contribution to educational thought on democracy is best understood. As such, the dawning of populism as an aspect of democratic education may facilitate for scholars and practitioners to oscillate between alternative ways of conceptualizing the people in their capacity as the foremost subject of contemporary education.

The contribution at hand is primarily realized through comparative and purpose-related readings (Säfström and Östman 1999) of John Dewey's Democracy and Education (1916/ 2004) and The Public and its Problems (1927) as well as Ernesto Laclau's On Populist Reason (2007). From this, the subsequent paper proceeds in three steps. Initially, an account of Dewey's conception of democracy and the public is provided, acknowledging its fundamental merits of affiliating education to the criteria of democratic life but also underscoring some of its faults in neglecting the constitutive role of human conflict. Secondly, and against this background, follows an interpretation of Laclau's theory of populism which explicates the notions of political demands, antagonism, empty signifiers and affect as a set of logical elements that are crucial to the enactment of democratic

\footnotetext{
${ }^{1}$ Readers are probably well aware of the role played by the right-wing party UKIP in the British public debate and that the recent presidential elections in the United States and the Philippines have been characterized by a populist rhetoric.
} 
education. Finally, conclusions are drawn with regard to populism as one particular educational modus through which teachers and students can articulate themselves as a democratic public. The paper ends with a discussion about the risks and possibilities involved in conceptualizing education from the point of view of a populist logic.

\section{A Democratic Conception of Education and the Public}

In Democracy and Education, Dewey states that the notion of education cannot be defined prior to any normative account of what kind of society is deemed desirable. Consequently, a democratic education can hardly be defined prior to any account of democracy. Dewey's (1916/2004) two criteria for democratic life, namely the plurality of interest that is shared within the group and the group's openness towards other groups, can be read not only as formal democratic criteria but also as educational ideals. This is what interweaves the notions of democracy and education in Dewey's argument and places his account beyond an instrumental and causal understanding of the relationship between the two.

Although Dewey (1916/2004) frames the democratic community in educational terms (by referring to growth, intelligence, and communication), he further develops his notion of democracy in The Public and its Problems as a societal and associative life in which the public is capable of defining itself. Dewey's notion of the public can, along with the notion of education, therefore be said to pave the way for his conception of democracy.

However, in our reading of Dewey's account of democracy, it is striking that references to 'the people' or 'demos' is scarcely to be found. Instead, notions such as 'community', 'associations', and 'the public' are placed in the foreground. As we understand it, the public comes into being when different individuals and groups recognize themselves as $a$ public in terms of sharing common interests and the consequences of each other's actions. In other words, the public becomes a public in and by its own articulations (Ljunggren 2003). In Dewey's conception of the public, and also in his criteria for democracy, the starting point is in the plurality and heterogeneity of society. This pluralism can be understood as both the plurality of interests within a group, and the plurality of groups within society.

By making pluralism the starting point, society cannot be seen as a fixed entity with a pre-given essence. Instead, Dewey defines society in contingent terms as the open and changeable constellation of overlapping groups: "Since there is no one thing which may be called a society, except their indefinite overlapping, there is no unqualified eulogistic connotation adhering to the term "society"' (Dewey 1927, p. 70). Given this, a democratic education cannot be regarded as an instrumental education that simply prepares students for specific future civic behavior, nor as a drilling in certain citizenship-oriented skills that can be safely stored for later use. Rather, a democratic education that stems from a deweyan philosophy is an education that revolves around the associated living with others. In this sense, a democratic education can be described as an associative life with others that is characterized by the interplay between belonging together on the one hand, and differing from each other on the other. It is in the open interplay between these aspects of associative life that democracy can be seen as "the idea of community life itself" (Dewey 1927, p. 148).

In our reading of Dewey, two points of criticism can nonetheless be highlighted as relevant. First, Dewey stresses the problem of making a sharp distinction between 'the individual' and 'the society', and instead puts forward the notion of associated activity as 
the starting point for both the individual and society. Dewey (1927) writes: "There is no sense asking how individuals come to be associated. They exist and operate in associations" (p. 23), and further on: "Associated activity needs no explanation; things are made that way" (p. 151). Thus, Dewey does not ask how associative life works, and does not give a conceptual account of how it came about that 'things are made that way'. In pointing this out, we are not suggesting an essentialist or foundational account on Dewey's behalf, but are rather stressing the need to explore what associative life entails in terms of the specific articulatory mechanisms and logics by which a community is constituted. Indeed, what is later argued in the paper is that the concept of populism exemplifies precisely how, and by which elements, a politically infused associative life works.

Second, in Dewey's conception of democracy, a group's internal and external openness are the main criteria. In this conceptualization, where society consists of overlapping associations, and where different interests can flourish both within and between groups, democracy seem to be exclusively characterized in harmonious terms. On a critical note, we could thus ask whether political conflicts, in terms of the boundaries between 'us' and 'them', have a place in Dewey's conception of democracy. Put differently, is democracy as defined by Dewey synonymous with the eradication of all antagonisms?

Although Dewey acknowledges that conflicts will arise in a democracy, he does not conceive them as an ontological condition for the emergence of the public as such. In other words, his conception of democracy implies an idea of conflict, but not of antagonism. Referring to Mouffe, Todd (2011) underlines that Dewey's theory "is not directly tied to an understanding of the political as a 'dimension of antagonism... constitutive of human societies"” (Todd 2011, p. 104). Instead, what Dewey foregrounds is the moral and social aspect of democracy. To use Dewey's own words, democracy "as a way of personal life is to realize that democracy is a moral ideal and so far as it becomes a fact is a moral fact" (1939/1988, p. 228). In short, we align with Straume's (2016) argument that Dewey fails to distinguish the social aspects of democracy from its political dimension. This becomes especially clear in how, from Dewey's perspective, a community of individuals is seemingly and only held together from within, based on their shared interests and in response to the consequences of their joint actions.

Given that Dewey's theory is first and foremost a moral and a social account, the need to explicate the political equivalent in democracy (and democratic education) becomes clear. Thus, for the specific purpose of this paper, Dewey's theory may facilitate thoughts about democratic education, but does not help us to reflect on an inherently political phenomenon such as populism. If we only read Dewey, it is difficult to determine how, and to what extent, populism could contribute to the enactment of the public's democratic education. ${ }^{2}$ With this in mind, what seems to be missing in Dewey's democratic account is the role of the antagonistic other. Although Dewey dissolves any unnecessary distinction between 'I' and 'we', he tends to leave 'them' out of the picture. With reference and objection to his argument that the public has to define itself, it is pertinent to ask: can there be a public without a public enemy?

To clarify, by highlighting the constitutive role of 'them' in the formation of 'us', we are not suggesting that the other needs to be an existing enemy or adversary. What we are underlining is only this; for the articulation of an associative life, and for the public's definition of itself, there needs to be some notion of who we are not. In order to further

\footnotetext{
${ }^{2}$ We are, of course, aware that Dewey does not explicitly discuss populism for obvious historical reasons. Thus, it is not our intention to anachronistically criticize his account, but rather to highlight the relevance of addressing the contemporary issue of populism with Dewey's educational theory and legacy in mind.
} 
elaborate on how individuals come to co-exist in association, and what difference the notion of antagonism makes for democratic education, we now turn to Laclau's theory of populism.

\section{The Elements of a Populist Logic}

Like Dewey's account of the public, Laclau's (2007) conception of populism starts with a notion of plurality. For the latter, it is the heterogeneous field of discursivity which makes any articulatory practice both possible and constitutive of social relations. However, the very same heterogeneity also makes any articulation unstable as it, within the wider field of discursivity, encounters its constitutive outside which prevents the articulation from achieving a fully sutured and objective meaning. When put into the context of populism, heterogeneity is thus both the condition for the emergence of the people and the condition for the impossibility of it ever attaining final closure. Consequently, any populist articulation is always an ontic attempt at standing in for the ontological absence of the people's essence. Following this notion of heterogeneity, populism cannot be defined a priori as a composition of specific ideological contents (left- or right-wing), but rather as a particular mode of articulation. Subsequently, and according to Laclau (2005, 2007), populism is nothing more than a political logic through which the people constitutes itself.

This populist logic does, however, consist of a number of formal features or specific elements, the most basic of which are the demands posed by social agents. By Laclau's account (2007), a single social demand isolated from others can easily be satisfied by and subsequently absorbed into an already existing institutional system. But, when a multitude of disparate claims are left unsettled for a period of time (or in moments of extensive crisis), they are joined together, not because they have certain inherent features in common, but because none of them are being fulfilled. The emergence of a populist project thus presupposes that social demands cease to be posed individually and are instead articulated collectively as following "a logic of equivalence-i.e. one in which all the demands, in spite of their differential character, tend to aggregate themselves, forming what we will call an equivalential chain" (Laclau 2005, p. 37). Thus, social demands are not inherently populist, but rather constituted as such when posed in a certain mode of articulation. Indeed, as Ruitenberg (2010) has argued, the notion of demands has great relevance in the context of democratic education. Following Laclau, she argues that it is not sufficient for students to ethically acknowledge injustices and inequalities but that they should also act upon them collectively. Learning to articulate social demands in conjunction with others is thus vital for the political efficacy of young people, lest they will continuously be perceived as disengaged from the politics of contemporary society.

Furthermore, Laclau (2007) states that popular demands are always posed towards someone, or more precisely, to those already in power yet unwilling or unable to satisfy the claims. These disparate demands thus form an equivalential chain on the basis of sharing an antagonistic frontier with the institutional system that negates their fulfilment. According to Laclau (1990, 2014), mutual negativity is a central premise of antagonism, which means that each of the forces taking part in this particular kind of relationship prevents the other from achieving its full identity. As such, antagonism entails that there will always be a constitutive outside which will, in a final instance, limit the completion of any identity. However, as this outside or, rather, opposing antagonistic force cannot prevent the other without also affirming it, antagonism serves the double constitutive function 
of both enabling and hindering the construction of social identities. Or, as Laclau (2007) puts it with regard to populism:

[...] populism involves the division of the social scene into two camps. This division

[...] presupposes the presence of some privileged signifiers which condense in themselves the signification of a whole antagonistic camp (the 'regime', the 'oligarchy', 'the dominant groups', and so on, for the enemy; the 'people', the 'nation', the 'silent majority, and so on, for the oppressed underdog - these signifiers acquire this articulating role accordingly, obviously, to a contextual history). (Laclau 2007, p. 87)

In a word, the construction of 'we, the people' is always in need of a 'them, those others' in order to be articulated. However, this does not mean that the people is exclusively constituted from without, but equally so from within, through privileged signifiers that represent the chain of demands as a whole. Not only must, according to Laclau (2007), such a signifier come from the actual chain at hand, but it must also necessarily be empty, meaning that its articulation is imprecise enough for all the other demands to rally around it. An empty signifier such as 'equality' can, for instance, take on a variety of meanings, thereby making it possible for a number of otherwise disparate demands to subscribe their realization to it. As such, populism does not only seek to break with a failing or unresponsive hegemonic order, it also provides, through empty signifiers, a new one in which unsatisfied demands are promised to be fulfilled.

At this point it is worth stressing that empty signifiers are not without relevance in education. For instance, Szkudlarek $(2007,2011)$ argues that they give schooling its direction, in that empty signifiers establish educational totalities linking disparate practices together while at the same time making identification possible: "[...] in the course of schooling, key categories in curricula (like "culture", "nation", "democracy", "science", etcetera) are circulated as important and at the same time impossible to define or understand, and [...] their incomprehensibility is systematically produced. Schools are factories of empty signifiers and of subjects who are ready to use them in their quest for identity" (Szkudlarek 2011, p. 122).

Indeed, any populist operation would be impossible if the social agents involved in the naming of demands did not affectively and radically invest themselves in the practices at hand. With reference to psychoanalytic theory, Laclau (2007) therefore stresses that, in discourse, subjects find partially constituted objects to which they can attach and enjoy their longing for a fully sutured identity, or indeed, a perfect society. However, considering that any such longing ultimately falls short in the face of heterogeneity and antagonism, Laclau states that:

The object of investment can be contingent, but it is most certainly not indifferent - it cannot be changed at will. With this we reach a full explanation of what radical investment means: making an object the embodiment of a mythical fullness. Affect (that is, enjoyment) is the very essence of investment, while its contingent character accounts for the radical component of the formula. (Laclau 2007, p. 115)

In the context of education, a number of examples spring to mind when considering Laclau's notion of affect. Think, for instance, of the promises that educators and the public ascribe to the educational reforms suggesting numerous improvements to a school system in purported crisis. Or, imagine a teacher experiencing the fear of what might become of 
his or her students if they are not offered a proper citizenship education. In short, if empty signifiers can be said to mark the direction of an operational populist logic, affect and radical investment surely pertain to the force or gusto by which the logic advances.

In this regard, Laclau's theory of affect is not too dissimilar from Dewey's (1916/2004) educational notion of human interest, in the sense that we are attentive to and concerned about the consequences of our actions. By foreseeing the good fortunes or disasters that may follow from different courses of action, individuals are not only influenced by a certain practice, but will also attempt to affect it in return. The mutual affectivity of the practitioner and the object of a practice is what, in the words of Dewey, best can be described as interest: "To be interested is to be absorbed in, wrapped up in, carried away by, some object. [...] We say of an interested person both that he has lost himself in some affair and that he has found himself in it. Both terms express the engrossment of the self in an object" (Dewey 1916/2004, p. 121).

As illustrated throughout this section of the paper, several scholars have argued for the educational relevance of the individual elements that make up the populist logic. For instance, Ruitenberg (2010) stresses the importance of demands, whereas Szkudlarek (2007, 2011) and Dewey (1916/2004), respectively, emphasize the significance of empty signifiers and affect. Taken together, an overarching conceptual discussion pertaining to the populist features in democratic education must not only be deemed vital, but also promising.

At this point, and with our explicit references to the notions of antagonism and heterogeneity, it should nonetheless be clear that the populist logic is not omnipotent in its workings. It is, on the contrary, susceptible to breakdown on two counts should it not succeed in challenging a hegemonic order. To begin with, the equivalential chain of demands can be dissolved if the institutional system meets each of the social demands individually. According to Laclau (2005), this is always a possibility, considering that the uniqueness of each demand cannot be fully eradicated, but only momentarily weakened as it enters into a chain of equivalence. As such, the equivalential attempts made by a particular populist movement are caught in a tense interplay with the differential logic of the current hegemonic totality. Alternatively, populist projects can be broken down by a political act that contest their chief demand, effectively re-positioning their empty signifiers into alternative equivalential chains which divert (or at least blur) the project's direction.

As the concept in question is primarily understood in formal and ontological terms, in accordance with Laclau $(2005,2007)$, all political acts can nonetheless be said to adhere to the populist logic to varying degrees. Laclau makes the following claim: "To ask oneself if a movement is or is not populist is, actually, to start with the wrong question. The question[s] we should, instead, ask ourselves, is the following: to what extent is a movement populist? [...] to what extent does the logic of equivalence dominate its discourse?" (Laclau 2005, p. 45). Following this line of thought, one can at least humor the notion that the variety of political practices present in the context of democratic education are not exempt from the populist logic. For instance, if teaching truly is a political act, as some have argued (e.g. Apple 1975/1996; Englund 1986; Freire 1985/2001), the crucial question that scholars of educational theory need to ask themselves is: to what degree is any democratic education enacted through the elements of populism?

However, in the context of this argument, it is important to note that Laclau's theory has been challenged, as some scholars have claimed that populism has more features in common with totalitarianism than with democracy. For instance, Abts and Rummens (2007) argue that Laclau's account of populism results in an image of the people as a homogenous group, rather than a pluralist collective of individuals with certain democratic 
rights. More importantly, as 'the common people' are generally not only placed in vertical antagonism towards the elite strata of society, but also towards the bottom, Abts and Rummens (2007) claim that the populist logic is unable to fully cope with and tolerate the otherness of those individuals who are not regarded as belonging to the people. As such, it could be argued that a populist project fails to recognize its political opponents horizontally, i.e. as adversaries with whom it shares a common symbolic space. In short, legitimate questions have been raised regarding populism's ability to keep the place of power empty enough for it to be seized by society's true plurality, rather than eradicating it.

Disregarding this critique in a context of democratic schooling could certainly have problematic consequences. For this reason, we follow Ruitenberg (2009) who suggests that political frontiers in education must be drawn agonistically, which means that opponents are not envisioned as moral enemies best eliminated violently, but rather as political adversaries each putting the other into question by opposing their demands and contesting their vision of just societal relations. In short, while 'the people' may be a fiercely disputed signifier, in an educational context it should not be contested violently.

Furthermore, Stavrakakis (2004), has claimed that at times Laclau adheres too much to formalism when discussing 'the people' as populism's prime signifier. In criticizing Laclau's tendency to view any project or movement as populist as long as it contains a certain set of articulatory features, Stavrakakis cautions against relegating the 'the people' to the level of just any other signifier, such as 'worker' or 'woman'. For him, populism (like democracy) can only and ultimately be thought about with explicit reference to the people and, consequently, through a somewhat restricted kind of formalism.

Despite the objections mentioned in the previous paragraphs, it is, for the purpose of providing the reader with an educational notion of populism, worth stressing that Laclau and Dewey share a number of features that facilitate the possibility of bringing the former into dialogue with the latter. To begin with, both these theoreticians are primarily concerned with the emergence of the democratic subject within a wider field of heterogeneity and plurality. From this starting point, they respectively conceive the public and the people as capable of defining itself through articulation. In a word, Laclau and Dewey share the maxim that the making of the democratic subject is its own doing. Additionally, both acknowledge that the definition of the democratic subject, whether in terms of the public or the people, cannot be defined once and for all. On the contrary, the endeavor to articulate such a collective subject is a constant one considering that it not only lacks an essence but also exists under ever changing social conditions. Moreover, Dewey and Laclau present their respective arguments in terms of functionalism and formalism, meaning that the people and public alike can concern themselves with a wide array of actual matters. It is thus a number of formal criteria, rather than any context-specific issue, that determine whether or not a given articulation is to be regarded as creating the public and the people respectively. Finally, and following from the previous similarities, both theoreticians regard political practices as more than purely rational acts of government. Instead, they tend to emphasize that politics and democracy are fundamental ways for human beings to co-exist.

\section{Populism as an Educational Modus}

Following our accounts of Dewey and Laclau, certain features become especially important to highlight as we begin to draw conclusions regarding the populist aspect of democratic education. As we see it, two of the elements of populism-affective investment and 
equivalential chains of demands-are clearly compatible with Dewey's criteria of democracy. The plurality of interests within a group, and the group's openness towards other groups, are by no means downplayed when the elements of populism are considered. On the contrary, it could be argued that Laclau's account provides an answer to the question of how we come to exist through association. As we now know, the elements of populism underscore precisely how affective investments holds a group together, while the equivalential character of the chain of demands points towards the fact that populist projects are open-ended and may very well be extensive enough to incorporate the claims of others.

Although this paper has primarily explored the points where Laclau's theory of populism intersects with and contributes to Dewey's notion of democratic education, we are nonetheless aware of the crucial differences that exist between their respective accounts. One important difference is how they theoretically approach and assert social crises, i.e. those moments in which the sedimented practices of society are destabilized and partially dissolved. In The Public and Its Problems, Dewey (1927) outlines how the societal conditions of rapid technical and administrative development have become increasingly remote from mental and moral beliefs. This discrepancy is what Dewey considers the most significant obstacle in the public's attempt to define itself. As we read Dewey, this fragmentation of moral and social life, brought forth by instrumentalization, is what prevents the individual from recognizing that his or her own actions are interwoven with those of others. In a situation like this, the public faces difficulty in identifying the consequences of its own actions and experiences, which in turn hinders its attempts to articulate itself.

In contrast to Dewey's characterization of fragmentation as a problem for the public, Laclau's account points toward the possibilities that every destabilization carries. For Laclau, it is in the actual unstableness of the social and the lack of a final closure that articulations become possible. The degree of stability vis-à-vis the degree of fragmentation is, of course, historically contingent and varies between societies, although from Laclau's point of view, the lack of a final closure is an ontological condition for the social as such. The search for the social stability that Dewey expresses as a suitable state in which the public can define itself could, from a laclauian perspective, be seen as a longing that also limits the variety of possible articulations, and ultimately the ways in which the public can emerge. In short, while Dewey underscores that the fragmentation and destabilization of the social becomes "the eclipse of the public" (Dewey 1927, p. 110ff), Laclau argues that this unstableness constitutes a precondition for all articulations, which in our opinion includes those made by the public itself.

From our joint reading of Dewey and Laclau, we nonetheless conclude that populism has important implications for how democratic education may be perceived. To begin with, it should be apparent by now that we are not referring to populism as the normative endgoal of education, as in education for populism. Neither are we concerned with education in populism as a specific subject matter, although it is plausible that teachers engaged in citizenship education may review actual cases of this phenomenon in their professional practice. Rather, and in line with the functionalism of Dewey and the formalism of Laclau, we suggest that (at least in part) democratic education can be enacted through the elements of populism, by which teachers and students can articulate themselves as subjects and members of a democratic public. After all, democracy appeals to the people in terms of demos, just as populism appeals to populus. In this sense, every democratic articulation needs to draw, to some extent, on the elements of populism.

For instance, just as populist articulations cannot escape antagonism, democracy cannot evade societal conflicts and disagreements. Hence, by appealing to the people, both 
populism and democracy make use of the establishment of political frontiers. In short, what we argue is that a democratic education that stems from an associative and political understanding of democracy depend upon the notion of the people and cannot, subsequently, fully eliminate the elements of populism. Populism and its political logic must therefore be strictly conceived as a modus and set of means (amongst many) by which joint democratic action can be realized and engaged with.

By being enacted through this modus and its elements of affective investment, empty signifiers and equivalential chains of demands, democratic education seem to have the potential to also be an enactment of democracy as such. Formulated in deweyan terms, democratic education in the modus of populism is where the public defines itself as individuals acknowledge each other's interests and problems. Or, to put it in laclauian terms, it is where the people affectively articulate themselves in their shared recognition of the equivalences between each other's unsatisfied demands. Such a recognition can never be a closed totality, but rather a communicative process of re-articulation where the boundaries and frontiers of the people constantly are being re-drawn (cf. LehmannRommel 2000, p. 206). The possibility of posing and answering the questions "who are we?" and "who are we not?" can therefore be seen as constitutive for both the definition of the people and for the people's definition of itself as a democratic public.

\section{The Risks and Possibilities of Populism}

If democratic education cannot fully eliminate the elements of populism, as argued above, it is important that we discuss the extent to which teachers should embrace populism in their professional practices. Thus, this concluding discussion highlights the risks and possibilities of suggesting populism as an educational modus.

Indeed, it could be argued that by bringing the concept of populism into democratic education, education becomes a risky and uncertain endeavor. However, such a risk and uncertainty isn't necessarily intrinsic to populism but rather to democracy as such, and therefore intrinsic to every democratic education that takes its main concept seriously (c.f. d'Agnese 2016). The elements of populism that have been explored in this paper, such as affective investments and equivalential demands, are however not necessarily bound up with values that are central to democracy, like equality and freedom. Totalitarian articulations can indeed generate strong affects in people and establish equivalential chains between different anti-democratic demands. In this sense, affects and demands are not necessarily democratic in their constitution, but are still necessary components of a democracy that appeals to the people as a political subject (e.g. Mouffe 2005).

Opening education up to the elements of populism could therefore be an opening for affects and demands that are not directed towards a democratic life. It would then seem to be crucial that an education that engages with populism is attentive to both the content and the direction of affects and demands. Just as an empty signifier can only be evaluated with regard to its general consequences, as Szkudlarek (2011) points out, the evaluation of populist elements in education need to be evaluated against their democratic consequences. If we depart from a deweyan conception of democracy, such an evaluation would be carried out with reference to the plurality of interest shared within a group and the group's openness towards others. Even if opening up education to the elements of populism is risky, it is possible that the generated affects are directed towards an associative life with others and that the articulated demands will be open to the plurality of interest within and 
between communities. Formulating demands and connecting them to the demands of other groups could, after all, be the act in which the public defines itself as a public, with shared interests and a shared faith in the consequences of its actions.

In order to further elaborate on this from the point of view of normativity, tangible examples of populism in an educational setting are needed. One such example would be to ask whether a teacher should enable articulations that frame 'the people' as a unity standing against 'the political elite'. An educational articulation that frames the European people as standing against refugees and politicians supporting immigration would be highly questionable, especially considering Dewey's criteria for an open and communicative democratic life. However, this does not mean that it is the populist logic as such that creates democratic problems like racism. From an historical perspective, the articulations of frontiers between 'the people' and 'the elite' have played a central role in the democratization of several countries. For instance, the numerous anti-colonial struggles during the twentieth century, or the ANC's struggle in South Africa, clearly testify to the democratic significance of such articulations (e.g. Howarth 2005). Thus, if the elements of populism are present in a classroom, the main question is whether or not they would vitalize the democratic ethos of young people, and thereby be an antidote to the political apathy, resentment and indifference that Dewey (1927, p. 118; 134f) outlines as a threat to democratic life.

Furthermore, if populism is a simplification of politics (in neither a positive nor a negative sense), as Laclau asserts, it could play a crucial role in mobilizing young people's affects for a democratic living. Put differently, if (on the contrary) democratic politics is continuously and too heavily framed as a phenomenon that is impregnated by differences, details and paradoxes, why should we believe that students will affectively mobilize and engage in the political practices we deem desirable?

One criticism of this account is that a simplification of politics would reinforce dispositions of uncritical thinking and foster epistemological ignorance towards social facts in ways that limit democratic life. In this sense, a simplification of politics in education would reduce students' ability to critically deliberate and participate as citizens. Furthermore, a critic could say that rather than having a simplified understanding of democratic politics, young citizens need to be able to identify the differences between facts and values and be aware of the nuances, complexities and multiplicity of perspectives present in democracy. In this line of reasoning, a simplification that blurs these differences could actually make students more vulnerable and susceptible to propaganda.

However, this criticism is from our laclauian understanding of populism, and subsequently our understanding of the simplification of politics, unmistakably beside the point. The critique at hand rests upon the misconception that a simplification is a reduction of differences. From Laclau's point of view of populism, a simplification of politics does not reduce the differences between political demands, but instead makes the demands equivalential to each other. Thus, if populism is understood as a modus that simplifies politics, this does not mean that the plurality of demands and interests within and between groups is reduced. What it does mean is that this plurality is articulated and arranged equivalently.

By raising these questions, we are not advocating that populism should be warmly embraced by teachers in their classrooms. Neither are we suggesting that populism should be avoided by educators in their professional practices. In our view, such considerations are ultimately a question for teachers to decide, given their particular political and historical context. However, what we are arguing is that the notion of populism is of significant relevance for democratic education, and therefore needs to be more thoroughly addressed by educational scholars. As such, the account put forward in this paper has 
aspired to contribute by bringing about the dawning of a new and integral aspect of democratic education. In short, this account is one that specifies the elements of populism as a set of means enabling those political and educational articulations by which the collective democratic subject undergo the consequences of its actions. Moreover, it is an account that supplements any congenial conception of democratic education with an understanding that associative life can never be articulated solely in positive terms, but that it is always dependent on the articulation of a 'them' as 'our' constitutive other. In these articulations, affective investments in the signifiers that draw the boundaries of associative life are ultimately what makes democracy worthwhile.

Acknowledgements The authors wish to thank their respective research environments, SMED (Studies of Meaning-Making in Educational Discourses) and Education and Democracy, for their critical readings of this article. The authors also wish to show special gratitude to Jim Garrison and Yannis Stavrakakis who commented upon early drafts and provided the authors with valuable insights.

Funding The presented inquiry was conducted within the research school of UVD (Educational Sciences with an Emphasis on Didactics) funded by LUN (The Board of Teacher Education) at Örebro University.

\section{Compliance with Ethical Standards}

Conflict of interest The authors declare that they have no conflict of interest.

Open Access This article is distributed under the terms of the Creative Commons Attribution 4.0 International License (http://creativecommons.org/licenses/by/4.0/), which permits unrestricted use, distribution, and reproduction in any medium, provided you give appropriate credit to the original author(s) and the source, provide a link to the Creative Commons license, and indicate if changes were made.

\section{References}

Abts, K., and S. Rummens. 2007. Populism versus democracy. Political Studies 55 (2): 405-424.

Apple, M. 1975/1996. The hidden curriculum and the nature of conflict. In Educating the democratic mind, ed. W.C. Parker, 173-199. Albany: State University of New York Press.

Biesta, G. 2011. The ignorant citizen: Mouffe, Rancière, and the subject of democratic education. Studies in Philosophy and Education 30 (2): 141-153.

Conroy, J.C. 2010. The state, parenting, and the populist energies of anxiety. Educational Theory 60 (3): $325-340$.

D'Agnese, V. 2016. Undergoing, mystery, and half-knowledge: John Dewey's disquieting side. Studies in Philosophy and Education 35 (2): 195-214.

Dewey, J. 1916/2004. Democracy and education. Mineola: Dover.

Dewey, J. 1927. The public and its problems. Athens: Swallow Press, Ohio State University Press.

Dewey, J. 1939/1988. Creative democracy-The task before us. In John Dewey. The later works, 19251953: 1939-1941, vol. 14, ed. J.A. Boydston, 224-230. Carbondale and Edwardsville: Southern Illinois University Press.

Englund, T. 1986. Curriculum as a political problem: Changing educational conceptions, with special reference to citizenship education. Lund/Bromley: Studentlitteratur/Chartwell-Bratt.

Freire, P. 1985/2001. Reading the world and reading the word: An interview with Paulo Freire. In Philosophy of education: Introductory readings, ed. W. Hare and J.P. Portelli, 145-152. Calgary: Detselig Enterprises [reprint from Language Arts 62(1): 15-21].

Howarth, D. 2005. Populism or popular democracy? The UDF, workerism and the struggle of radical democracy in South Africa. In Populism and the mirror of democracy, ed. F. Panizza, 202-223. London: Verso.

Laclau, E. 1990. New reflections on the revolution of our time. London: Verso.

Laclau, E. 2005. Populism: What's in a name? In Populism and the mirror of democracy, ed. F. Panizza, 32-49. London: Verso. 
Laclau, E. 2007. On populist reason. London: Verso.

Laclau, E. 2014. The rhetorical foundations of society. London: Verso.

Lauglo, J. 1995. Populism and education in Norway. Comparative Education Review 39 (3): 255-279.

Lehmann-Rommel, R. 2000. The renewal of Dewey-Trends in the nineties. Studies in Philosophy and Education 19 (1-2): 187-218.

Ljunggren, C. 2003. The public has to define itself: Dewey, Habermas, and Rorty on democracy and individuality. Studies in Philosophy and Education 22 (5): 351-370.

Merryfield, M.M., and L. Duty. 2008. Globalization. In SAGE handbook of education for citizenship and democracy, ed. J. Arthur, I. Davies, and C. Hahn, 80-91. London/Thousand Oaks: SAGE.

Mouffe, C. 2005. The 'end of politics' and the challenge of right-wing populism. In Populism and the mirror of democracy, ed. F. Panizza, 50-71. London: Verso.

Norval, A. 2007. Aversive democracy: Inheritance and originality in the democratic tradition. Cambridge: Cambridge University Press.

Pollock, G., T. Brock, and M. Ellison. 2015. Populism, ideology and contradiction: Mapping young people's political views. The Sociological Review 63 (2): 141-166.

Ruitenberg, C. 2009. Educating political adversaries: Chantal Mouffe and radical democratic citizenship education. Studies in Philosophy and Education 28 (3): 269-281.

Ruitenberg, C. 2010. Learning to articulate: From ethical motivation to political demands. In Philosophy of education 2010, ed. G. Biesta, 372-380. Urbana: Philosophy of Education Society.

Säfström, C.A., and L. Östman. 1999. Textanalys [Textual analysis]. Lund: Studentlitteratur.

Spector, H. 2015. The who and the what of educational cosmopolitanism. Studies in Philosophy and Education 34 (4): 423-440.

Spruyt, B. 2014. An asymmetric group relation? An investigation into public perceptions of education-based groups and the support for populism. Acta Politica 49 (2): 123-143.

Stavrakakis, Y. 2004. Antinomies of formalism: Laclau's theory of populism and the lessons from religious populism in Greece. Journal of Political Ideologies 9 (3): 253-267.

Straume, I.S. 2016. Democracy, education and the need for politics. Studies in Philosophy and Education 35 (1): 29-45.

Szkudlarek, T. 2007. Empty signifiers, education and politics. Studies in Philosophy and Education 26 (3): 237-252.

Szkudlarek, T. 2011. Semiotics of identity: Politics and education. Studies in Philosophy and Education 30 (2): 113-125.

Tjeldvoll, A. 2002. The decline of educational populism in Norway. European Education 34 (3): 61-76.

Todd, S. 2011. Educating beyond cultural diversity: Redrawing the boundaries of a democratic plurality. Studies in Philosophy and Education 30 (2): 113-125. 